\title{
LPP Gene
}

National Cancer Institute

\section{Source}

National Cancer Institute. LPP Gene. NCI Thesaurus. Code C97610.

This gene may be involved in cell shape and cell motility. 